\title{
Dual Specificity Protein Phosphatase 1
}

National Cancer Institute

\section{Source}

National Cancer Institute. Dual Specificity Protein Phosphatase 1. NCI Thesaurus. Code C29568.

Dual specificity protein phosphatase 1 (367 aa, $\sim 39 \mathrm{kDa}$ ) is encoded by the human DUSP1 gene. This protein plays a role in the dephosphorylation of mitogen-activated protein kinase 1. 